\title{
Biomedical Applications \\ of Nano-Sized Polymeric Micelles and Polyion Complexes
}

\author{
Alexander Kabanov* \\ University of North Carolina at Chapel Hill \\ 125 Mason Farm Road, Chapel Hill, NC 27599-7362, USA \\ M.V. Lomonosov Moscow State University \\ 1 Leninskie Gory, Moscow, 119991, Russia
}

Received 06.02.2018, received in revised form 11.04.2018, accepted 02.05.2018

The paper provides a high-level overview of the use of polymeric micelles, polyion complexes, cell mediated drug carriers and exosomes in the therapy of cancer and neurodegenerative diseases. The author tries to combine the lessons-learned during over a quarter of century work in the field of nanomedicine and drug delivery along with a vision statement of some trends and future prospective in this field. Several most recent examples from the University of North Carolina and Moscow State University laboratories are presented including high capacity polymeric micelles for single and multiple water-insoluble drugs for cancer therapy. The nanoscale size polyion complexes formed by ionic block copolymers and polypeptides for the delivery of these polypeptides are also discussed. Examples include antioxidant enzymes (e.g. superoxide dismutase, catalase), stoichiometric and catalytic scavengers of organophosphorus toxins (butirylcholine esterase, organophosphate hydrolase) and neurotrophins (brain-derived neurotrophic factor, glial cell line-derived neurotrophic factor). The applications include treatments of obesity, stroke, Parkinson's disease, RETT syndrome, organophosphorus toxins poisoning, and some other medical conditions that have been demonstrated using animal models. The application of these complexes in the context of the macrophage carriers for drug delivery to the site of inflammation is presented. A concept of the use of genetically modified macrophages as natural gene delivery vectors is stated and illustrated using Parkinson's disease therapy as an example. The role of exosomes in gene and protein delivery and its potential as a true pharmaceutical modality are also discussed.

Keywords: nanomedicine, drug delivery, polymeric micelles, polyion complexes, drug carriers, exosomes.

Citation: Kabanov A. Biomedical applications of nano-sized polymeric micelles and polyion complexes. J. Sib. Fed. Univ. Biol., 2018, 11(2), 110-118. DOI: 10.17516/1997-1389-0053.

(c) Siberian Federal University. All rights reserved

* Corresponding author E-mail address: kabanov@email.unc.edu 


\title{
Биомедицинские применения \\ наноразмерных полимерных мицелл \\ и полиионных комплексов
}

\author{
А. Кабанов \\ Университет Северной Каролины в Чапел-Хилл \\ США, 27599-7362, Северная Каролина, \\ Чапел-Хилл, Масон Фарм Роад, 125 \\ Московский государственный университет им. М.В. Ломоносова \\ Россия, 119991, Москва, Ленинские горы, 1
}

В работе представлен обзор по использованию полимерных мицелл, полиионных комплексов, опосредуемых клетками носителей и экзосом в терапии рака и нейродегенеративных заболеваний. В обзоре рассмотрены основные разработанные в последние десятилетия подходы в области наномедицины и доставки лекарств, а также некоторые тенденции и будущие перспективы в данной области. Представлено несколько последних разработок лабораторий Университета Северной Каролины и Московского государственного университета им. М.В. Ломоносова, включая высокомолекулярные полимерные мицеллы для одного и нескольких нерастворимых в воде лекарств. Обсуждаются наноразмерные полиионные комплексы, образованные ионными блок-сополимерами и полипептидами для доставки этих полипептидов. Примеры включают антиоксидантные ферменты (например, супероксиддисмутаза, каталаза), стехиометрические и каталитические поглотители фосфорорганических токсинов (бутирилхолинэстераза, органофосфатгидролаза) и нейротрофины (нейротрофический фактор мозга, нейротрофический фактор, полученный из глиальных клеток). Применение разработанных форм продемонстрировано на моделях животных и включает терапию ожирения, инсульта, болезни Паркинсона, синдрома Ретта, отравление фосфорорганическими токсинами и др. Представлено применение полиионных комплексов для доставки лекарств в макрофаги. В качестве примера изложена и проиллюстрирована концепция использования генетически модифицированных макрофагов в качестве естественных векторов доставки генов. Также обсуждена роль экзосом в доставке генов и белков и их потенциал в качестве нового фармацевтического подхода терапии.

Ключевые слова: наномедицина, доставка лекарственных средств, полимерные мицелль, полиионные комплексы, носители лекарственных средств, экзосомы.

The purpose of this report is to briefly describe the current state of research in the field of "Nanomedicine and directed drug delivery". No doubt, today it is a huge and rapidly developing field. The course of lectures I give for students and graduate students at the Faculty of Chemistry in Lomonosov Moscow State University is devoted to this research field. I am lucky enough to work in this field almost from the time it appeared since the end of the 1980s, 
and together with Russian and international colleagues to carry out a number of studies that have influenced its development. In this regard, with the example of some of these studies, I will try to give my vision of the historical context and trends in the development of nanomedicine and drug delivery.

The nanomedicine approach is based on the use of nano-sized supramolecular particles as containers for the delivery of biologically active substances. By the end of the 80 s, when we were just starting our work in this field, liposomes were actively studied and they were the first nanopreparations, applied in the clinic. Liposomes have an internal water reservoir, which is well used for the inclusion of hydrophilic substances delivered (for example, doxorubicin in the anticancer drug Doxil). However, with some exceptions, they are not very well suited for delivery of hydrophobic substances. The reason is that in the lipid bilayer, which is the basis of the vesicular structure of liposomes, there is usually not too much room for hydrophobic compounds to be included without a significant change in the structure of this bilayer.

A successful alternative for the inclusion of hydrophobic substances were micelles of amphiphilic block copolymers. In such micelles, insoluble polymer chains (blocks) form a hydrophobic core, and hydrophilic blocks create a water-soluble corona that retains micelles in the dissolved (dispersed) state. The polymer chains in the hydrophobic core of the micelle have sufficient "mobility" and can "make room" to include a significant amount of waterinsoluble drug compounds without significantly altering the overall structure of the micelle (core-corona). In the late 80 -ies we carried out research in collaboration with V.P. Chekhonin and other colleagues and we used polymeric micelles for the brain-targeted delivery of non-covalently incorporated ("solubilized") biologically active substances for the first time (Kabanov et al., 1989). Soon this field got a widespread development and was continued by the efforts of many laboratories, including ours, as well as prof. K. Kataoka in Japan and many others. Today, over a dozen of polymeric micelles-based drugs are in clinical trials and one drug developed in Korea, Genexol PM, has been approved for use in the treatment of breast, lung (NSCLC) and ovarian cancer.

In this regard, it should be mentioned that the world's first polymeric micelles-based drug, tested in the clinic was SP1049C, containing doxorubicin in micelles of poloxamers (also known as "Pluronic"), which we developed together with V.Yu. Alakhov and Supratek Pharma (Canada). The concept of this drug was based on the phenomenon of a significant increase in the sensitivity of cancer cells resistant to therapy under the influence of poloxamers (Pluronics) of a certain structure (Alakhov et al., 1996). We established the mechanisms of this phenomenon, including the interaction of poloxamers with membrane pumps and the mitochondrial respiratory chain (Batrakova et al., 2001; Alakhova et al., 2010), and showed that this drug effectively kills not only multidrug-resistant tumors, but also tumor-initiating cells, and, on the whole, significantly increases the effectiveness of cancer treatment. Today, this drug successfully has passed the first and second phase of clinical trials for the treatment of upper gastrointestinal cancer and has reached the third phase.

Thus, polymeric micelles for drug delivery have become a reality in the clinic, and certainly, one should expect the market entry of many new drugs on this basis. New promising directions in this area include polymeric micelles of block copolymers of poly (2-oxazoline) with exceptionally high loading of hydrophobic drugs, reaching $50 \%$ of the weight of the micelle itself. For example, we recently created paclitaxel 
preparations in which the drug's effective load exceed the drug content in Abraxan and Taxol, respectively, 10 and 100 times. Due to a sharp decrease in the content of polymer carriers and the possibility of increasing the concentration of the drug administered, the safe dose of the drug also significantly increases, which makes it possible to enhance the therapeutic effect (He et al., 2016). In animal models, the possibility of simultaneous administration of several chemotherapeutic drugs included in one micellar container is shown, which not only simplifies the practical application of combined chemotherapy "in one", but also increases the effectiveness of these drugs by simultaneously delivering them to tumor cells.

Close to these studies are adjacent studies in the field of nano-gels and cross-linked polymeric micelles as drug delivery containers. We first used nano-gels from covalently linked polymer chains to deliver oligonucleotides, and then developed this approach for low molecular weight compounds, for example, cisplatin derivatives and combinations of these derivatives with other drugs (Vinogradov et al., 2002; Kabanov, Vinogradov, 2009).

By introducing chemical crosslinks between polymer chains the stability of the particle delivered in the body is achieved. By using bio-cleavable crosslinks it is possible to achieve controlled drug-release and destruction of the container at the end of its operation. Due to the stability of such a container in the body, it is possible to address it by antibodies or other biospecific molecules attached to the container (Nukolova et al., 2011, 2013).

An important role is played by the fact that nano-gels, swollen in water and polymeric micelles are poorly adsorbed on the surface of non-target cells, which improves the specificity of their delivery to target cells. In addition, by varying the number of cross-links it is possible to vary the swelling of nano-gels and their elasticity, which in principle can be used to improve their penetration into the tumor.

Returning to the origins of our work in the field of nanomedicine back into the late 80-ies in cooperation with V.A. Kabanov and V.I. Kiselev, we showed the possibility of packaging plasmid DNA by forming a polyelectrolyte DNA complex with polycations for the purpose of cell delivery (Kabanov et al., 1989, 1993). Such compact nanoscale complexes were subsequently called "polyplexes", and they were prototypes of modern polycation - based cell transfection systems, which are now very widely used in laboratories. However, the limitation of such system was that to ensure the stability of polyplex nanoparticles in aqueous media it is necessary to add a large excess of polycation, which increases the toxicity of polyplexes, and, most importantly, makes it difficult to use them in a living organism due to the adsorption of seum proteins and aggregation of such particles in the blood.

The key solution was to use cationic block copolymers containing uncharged water-soluble chains such as, for example, polyethylene glycol (Kabanov et al., 1995). As a result, it became possible to obtain uncharged nanoscale polyelectrolyte micelles with a core of mutually neutralized nucleic acids and polycations and a corona of uncharged polymer chains. We called them "block-ionomer complexes" and carried out a wide range of research of the physical and chemical basis of formation, stability, and dynamic transformations of such complexes of various structures. From the point of view of nanomedicine and drug delivery, it is important that such particles are significantly less toxic and adsorb proteins to a far lesser extent. At present, they are being investigated by many laboratories for the development of directional delivery systems of nucleic acids in the body, including the tumor-targeted delivery of short interfering 
RNA (research carried out at Moscow State University).

This approach turned out to be universal for the inclusion of not only nucleic acids, but also other biopolymers, in particular, proteins. Our works in this direction first focused on the creation of nanoscale complexes of enzymes, which we called "nanozymes". Just as in the case of nucleic acids, such complexes are formed spontaneously when mixing the aqueous solutions of the protein and the corresponding block copolymer, in this case, either cationic or anionic, depending on the charge of the protein. The structure of the complexes is also characterized by the presence of a nucleus in which the enzyme molecules bound to the polyelectrolyte block and a hydrophilic corona formed from uncharged polymer chains are located. Crucially, the enzymes included in such structures retain the catalytic activity, and as a result nanozymes have the activity of the initial enzyme. A common thing for such systems is the significant stabilization of the proteins included in them, in particular, against proteolytic cleavage after the capture of nanozymes into cells, where the nanozymes remain active for hours and even days (Manickam et al., 2012).

One example of the use of the nanozyme approach was demonstrated by us at Moscow State University in the framework of the grant from the Government of the Russian Federation.

In these studies we used a bacterial enzyme, organophosphate hydrolase, capable of cleavage of highly toxic organophosphate compounds used as pesticides and chemical warfare agents. This enzyme, obtained at the Department of Chemical Enzymology of Moscow State University is very active, however, its disadvantage is the relatively low stability and bacterial origin that makes it difficult to use in the body. We have shown that by including organophosphate hydrolase into a polyelectrolyte complex with a block copolymer of polyglutamic acid and polyethylene glycol, the stability of this enzyme can be significantly increased (the aqueous solution is stored without a significant change in activity up to two years), reduce the immune response, and increase the half-life when the enzyme is introduced into the body. Preparations of nanozyme organophosphate hydrolase with intravenous, intramuscular, and, in fact, buccal administration provide protection against multiple lethal doses of organophosphate pesticides and a warfare agent VX.

We also used this approach to create nanozymes based on antioxidant enzymes capable of cleaving toxic reactive oxygen species and thereby preventing tissue degeneration in various inflammatory processes. Stabilization of enzymes in nanozymes in combination with an increase of its circulation time and the ability to penetrate into the cells proved to be essential for improving the biological activity of the obtained nano-formulations. Thus, for example, superoxide dismutase 1 nanozymes were successfully used in animal models for neuroprotection in cerebral stroke, lowering blood pressure in heart failure and angiotensin II-stimulated hypertension, reducing inflammation of adipose tissue and aorta in obesity and in a number of other pathologies (Rosenbaugh et al., 2010; Jiang et al., 2015; Perriotte-Olson et al., 2016).

The nanozyme preparation of superoxide dismutase 1 developed to in our laboratory at Moscow State University showed significant therapeutic activity in the treatment of inflammatory diseases of the eye and is now undergoing preclinical research with the support of the federal program "Development of the pharmaceutical and medical industry of the Russian Federation until 2020" (Kost et al., 2016).

It should be noted that in addition to enzyme preparations, the described approach can be successfully applied for the delivery of polypeptides. In particular, we have shown the possibility of improving delivery of brain- 
derived neurotrophic factor (BDNF) to the brain. This hydrophobic and aggregationunstable polypeptide in aqueous solutions easily forms nanoscale stable complexes with a block copolymer of polyglutamic acid and polyethylene glycol. Moreover, these complexes are formed not only due to electrostatic, but also due to combinations of hydrophobic interactions and hydrogen bonds. Due to this, such complexes are unusually stable, but they easily rebuild and release neurotrophin upon interaction of the latter with the receptor (TrkB), whereby nano-BDNF is practically as active as the original protein. We have shown that the incorporation of BDNF into this complex significantly improves the delivery of this neurotrophin to the brain, both with intravenous and intranasal administration. Moreover, in studies of cerebral stroke in animal models, a significant improvement in the neuro-regenerative effect of BDNF has been demonstrated through the use of such nanoformulation (Harris et al., 2016).

Many pathologies, in particular those related to brain diseases, are associated with the development of inflammatory processes during which infiltration of immune cells, including monocytes/macrophages, occurs that promote the oxidative stress of the leading degeneration of tissues. This occurs, for example, in Parkinson's disease. We decided to use this circumstance to create a therapeutic approach, using the Trojan Horse principle. In this approach, the enzymes catalase nanozymes are loaded into macrophages in which they can exist for a very long time and from which are gradually released, while retaining catalytic activity. After introduction into the bloodstream of animals with an experimental model of Parkinson's disease, such loaded macrophages accumulate in the area of disease and inflammation in the brain where the active nanozyme catalase is released and cleaves the hydrogen peroxide produced by macrophages. Thus, in animal models of Parkinson's disease, a reduction in inflammation is achieved and a significant neuroprotective effect is observed, which is expressed in the preservation of dopaminergic neurons (Brynskikh et al., 2010).

The use of macrophages as drug delivery systems is counterintuitive for nanomedicine. In all the early works in this field, the task was to create such nanopreparations that would avoid capture by macrophages, acting as "cleaners" of the organism from alien objects. At the same time, already during the work on the mechanism of delivery of the "bare" plasmid DNA after its injection into the skeletal muscle, we noticed that in the phenomenon of a sharp increase in the expression of genes in the presence of poloxamers (Lemieux et al., 2000; Yang et al., 2005) an important role is played by cells of the immune system and, first of all, macrophages. It turned out that when injected into the muscle with DNA, along with the poloxamer, which acts as a kind of "adjuvant" that activates the cells of the immune system, macrophages efficiently capture DNA, and not only transmit it to muscle cells, but can deliver it to distant organs from the injection site, in particular the lymph nodes and spleen (Gaymalov et al., 2009). It also turned out that the macrophages that captured DNA in the cell culture can "horizontally" transfer this DNA to cells of another type-muscles, neurons, cancer cells, while DNA is expressed in these new cells, even if it cannot be transcribed in the originally captured cells macrophages (Mahajan et al., 2016). Thus, transfected macrophages can act as "gene delivery systems" in other cells, including inflammation sites for various diseases. The principal possibility of this approach was demonstrated in models of Parkinson's disease, when macrophages, trabsfected with catalase or glial cells derived neurotrophic factor (GDNF) were administered to animals. In both cases, the 
macrophages administered into the bloodstream not only migrated to the brain, delivering the corresponding genes, but also ensured the effective expression of these genes, leading to significant neuroprotection (Haney et al., 2013; Zhao et al., 2014).

While studying the mechanisms of the transfer of nanosymes and DNA from macrophages to other cells we found that along with intercellular contacts, macrophages can also "repackage" the material contained in them and isolate it with the composition of exosomes nanoscale extracellular vesicles. Exosomes contain many elements of the macrophage membrane and, like them, can accumulate in inflamed areas, particularly in the brain, transferring the material contained in them into new cells. Thus, modified exosomes can act as natural nanoparticles for drug delivery, and this new direction has recently been rapidly developing. In particular, the animal model has demonstrated the possibility of delivering a therapeutic protein included in exosomes into the brain to treat Parkinson's disease (Haney et al., 2015).

In general, over the past quarter century in the field of nanomedicine and drug delivery new drugs have been introduced in the clinic and technologies have been developed to incorporate virtually any biologically active substances into biocompatible nanoscale containers. Moreover, it has become more understandable how these containers carry the included biologically active substances in the body and interact with healthy and diseased tissues. Approaches for non-invasive tracking of the processes of container transfer in the body have been developed. However, after the introduction of such containers into the body, we actually do not have the ability to control their function at the nanoscale, we cannot release medicines from them, turn them on or off at our discretion when they reach the target cells. Although this sounds almost fantastic today, the future development of science will undoubtedly go in this direction, and today we are already searching for fundamental opportunities for remote control of nano-drugs. One such possibility relates to the use of magnetic fields and superparamagnetic nanoparticles. While working in the framework of the grant of the Government of the Russian Federation in Moscow State University in cooperation with Tambov State University experimental installations for creating alternating magnetic fields of ultralow frequency have been developed and built. Such fields do not cause the heating of magnetic nanoparticles, but lead to their mechanical perturbation and the creation of a force that is transferred to the molecules of polymers attached to these particles. First, the possibility of a remote change in the rate of a biochemical reaction, catalyzed by an enzyme immobilized in a cluster of magnetic nanoparticles by an external non-heating alternating magnetic field was shown (Klyachko et al., 2012). It has also recently been established that within this "magneto-mechanical" approach, using an ultra-low frequency field of $50 \mathrm{~Hz}$, it is possible to act on the cell from the inside, in particular, to destroy the cytoskeleton of cancer cells into which magnetic nanoparticles are preliminarily delivered (Master et al., 2016). Remarkably, the destruction of the cytoskeleton in normal epithelial cells does not occur, but occurs in cancerous cells because they have a less stable cytoskeleton.

Thus, the principle possibility of selective remote action on cancer cells with the help of external magnetic fields has been demonstrated. It is hoped that this and other similar approaches will be substantially developed in the nearest future and will lead to improving methods of diagnosing and treating human diseases. 


\section{References}

Alakhov V.Y., Moskaleva E.Y., Batrakova E.V., Kabanov A.V. (1996) Hypersensitization of multidrug resistant human ovarian carcinoma cells by pluronic P85 block copolymer. Bioconjug. Chem., 7: 209-216

Alakhova D.Y., Rapoport N.Y., Batrakova E.V., Timoshin A.A., Li S., Nicholls D. (2010) Differential metabolic responses to pluronic in MDR and non-MDR cells: a novel pathway for chemosensitization of drug resistant cancers. J. Contr. Rel., 142: 89-100

Batrakova E.V., Li S., Elmquist W.F., Miller D.W., Alakhov V.Y., Kabanov A.V. (2001) Mechanism of sensitization of MDR cancer cells by Pluronic block copolymers: Selective energy depletion. $\mathrm{Br}$. J. Cancer, 85: 1987-1997

Brynskikh A.M., Zhao Y., Mosley R.L., Li S., Boska M.D., Klyachko N.L. (2010) Macrophage delivery of therapeutic nanozymes in a murine model of Parkinson's disease. Nanomedicine, 5: 379-396

Gaymalov Z.Z., Yang Z., Pisarev V.M., Alakhov V.Y., Kabanov A.V. (2009) The effect of the nonionic block copolymer pluronic P85 on gene expression in mouse muscle and antigen-presenting cells. Biomaterials, 30: 1232-1245

Haney M.J., Klyachko N.L., Zhao Y., Gupta R., Plotnikova E.G., He Z., Patel T., Piroyan A., Sokolsky M., Kabanov A.V., Batrakova E.V. (2015) Exosomes as drug delivery vehicles for Parkinson's disease therapy. J. Contr. Rel., 207: 18-30

Haney M.J., Zhao Y., Harrison E.B., Mahajan V., Ahmed S., He Z., Suresh P. (2013) Specific transfection of inflamed brain by macrophages: a new therapeutic strategy for neurodegenerative diseases. PLoS One, 8: e61852

Harris N.M., Ritzel R., Mancini N.S., Jiang Y., Yi X., Manickam D.S., Banks W.A. (2016) Nanoparticle delivery of brain derived neurotrophic factor after focal cerebral ischemia reduces tissue injury and enhances behavioral recovery. Pharmacol. Biochem. Behav., 150-151: 48-56

He Z., Wan X., Schulz A., Bludau H., Dobrovolskaia M.A., Stern S.T. (2016) A high capacity polymeric micelle of paclitaxel: Implication of high dose drug therapy to safety and in vivo anti-cancer activity. Biomaterials, 101: 296-309

Jiang Y., Brynskikh A.M., Devika S., Kabanov A.V. (2015) SOD1 nanozyme salvages ischemic brain by locally protecting cerebral vasculature. J. Contr. Rel., 213: 36-44

Kabanov A.V., Astafieva I.V., Maksimova I.V., Lukanidin E.M., Georgiev G.P. (1993) Efficient transformation of mammalian cells using DNA interpolyelectrolyte complexes with carbon chain polycations. Bioconjug. Chem., 4: 448-454

Kabanov A.V., Chekhonin V.P., Alakhov V., Batrakova E.V., Lebedev A.S., Melik-Nubarov N.S., Arzhakov S.A., Levashov A.V., Morozov G.V., Severin E.S., Kabanov V.A.(1989) Theneuroleptic activity of haloperidol increases after its solubilization in surfactant micelles. Micelles as microcontainers for drug targeting. FEBS Lett., 258: 343-345

Kabanov A.V., Kiselev V.I., Chikindas M.L., Astaf'eva I.V., Glukhov A.I., Gordeev S.A., Izumrudov V.A., Zezin A.B., Levashov A.V., Severin E.S., Kabanov V.A. (1989) Increasing the transforming activity of plasmid DNA by incorporating it into an interpolyelectrolyte complex with a carbon chain polycation. Doklady Biochemistry, 306: 133-136

Kabanov A.V., Vinogradov S.V. (2009) Nanogels as pharmaceutical carriers: finite networks of infinite capabilities. Angew. Chem. Int. Ed., 48: 5418-5429 
Kabanov A.V., Vinogradov S.V., Suzdaltseva Y.G., Alakhov V.Y. (1995) Water-soluble block polycations as carriers for oligonucleotide delivery. Bioconjug. Chem., 6: 639-643

Klyachko N.L., Sokolsky-Papkov M., Pothayee N., Efremova M.V., Gulin D.A., Pothayee N., Kuznetsov A.A., Majouga A.G., Riffle J.S., Golovin Y.I., Kabanov A.V. (2012) Changing the enzyme reaction rate in magnetic nanosuspensions by a non-heating magnetic field. Angew. Chem. Int. Ed., 51: 12016-12019

Kost O.A., Beznos O.V., Davydova N.G., Manickam D.S., Nikolskaya I.I., Guller A.E., Binevski P.V., Chesnokova N.B., Shekhter A.B., Klyachko N.L., Kabanov A.V. (2016) Superoxide dismutase 1 nanozyme for treatment of eye inflammation. Oxid. Med. Cell. Longev., 2016: 5194239

Lemieux P., Guerin N., Paradis G., Proulx R., Chistyakova L., Kabanov A. (2000) A combination of poloxamers increases gene expression of plasmid DNA in skeletal muscle. GeneTher., 7: 986-991

Mahajan V., Gaymalov Z., Alakhova D., Gupta R., Zucker I.H., Kabanov A.V. (2016) Horizontal gene transfer from macrophages to ischemic muscles upon delivery of naked DNA with pluronic block copolymers. Biomaterials, 75: 58-70

Manickam D.S., Brynskikh A.M., Kopanic J.L., Sorgen P.L., Klyachko N.L. (2012) Well-defined cross-linked antioxidant nanozymes for treatment of ischemic brain injury. J. Contr. Rel., 162: 636-645

Master A.M., Williams P.N., Pothayee N., Pothayee N., Zhang R., Vishwasrao H.M., Golovin Y.I., Riffle J.S., Sokolsky M., Kabanov A.V. (2016) Remote actuation of magnetic nanoparticles for cancer cell selective treatment through cytoskeletal disruption. Sci. Rep., 6: 33560

Nukolova N.V., Oberoi H.S., Cohen S.M., Kabanov A.V., Bronich T.K. (2011) Folate-decorated nanogels for targeted therapy of ovarian cancer. Biomaterials, 32: 5417-5426

Nukolova N.V., Oberoi H.S., Zhao Y., Chekhonin V.P., Kabanov A.V. (2013) LHRH-targeted nanogels as a delivery system for cisplatin to ovarian cancer. Mol.Pharm., 10: 3913-3921

Perriotte-Olson C., Adi N., Manickam D.S., Westwood R.A., Desouza C.V. (2016) Nanoformulated copper/zinc superoxide dismutase reduces adipose inflammation in obesity. Obesity, 24: 148-156

Rosenbaugh E.G., Roat J.W., Gao L., Yang R.F., Manickam D.S., Yin J.X. (2010) The attenuation of central angiotensin II-dependent pressor response and intra-neuronal signaling by intracarotid injection of nanoformulated copper/zinc superoxid. Biomaterials, 31: 5218-5226

Vinogradov S.V., Bronich T.K., Kabanov A.V. (2002) Nanosized cationic hydrogels for drug delivery: preparation, properties and interactions with cells. Adv.DrugDel.Rev., 54: 135-147

Yang Z., Zhu J., Sriadibhatla S., Gebhart C., Alakhov V., Kabanov A. (2005) Promoter-and strainselective enhancement of gene expression in a mouse skeletal muscle by a polymer excipient Pluronic P85. J. Contr. Rel., 108: 496-512

Zhao Y., Haney M.J., Gupta R., Bohnsack J.P., He Z., Kabanov A.V., Batrakova E.V. (2014) GDNFtransfected macrophages produce potent neuroprotective effects in Parkinson's disease mouse model. PLoS One, 9: e106867 